\title{
CURRENT UPDATE ON CANINE PARVOVIRUS IN VETERINARY FIELD ASPECT
}

\section{R. P. DIWAKAR, VIBHA YADAV, AWADESH KUMARYADAV \& SHIVENDRA MANI YADAV}

Department of Veterinary Microbiology, C. V. Sc \& A.H., N.D.U. A \& T., Kumarganj, Faizabad, Uttar Pradesh, India

ABSTRACT
Huge numbers of puppies are killed by parvovirus infection and this disease is transmitted by inanimate object as well as
insect and rodents. Parvovirus disease can be controlled by modified live virus vaccines, which are safe and effective to
control by adopting the vaccination protocol. CPV-2c strain not sassily detected in laboratory test and now no vaccine are
available to protect against that virus strain. So symptomatic treatment is done by the veterinarian and best is
vaccination, which play important role in control the disease mainly in puppies.
KEY WORD: Parvovirus

Received: Jul 28, 2017; Accepted: Aug 18, 2017; Published: Aug 29, 2017; Paper Id.: IJZROCT20171

\section{INTRODUCTION}

Canine parvovirus infection is mainly the diseases of young pups and adult dogs. Binn et al., (1970) first recovered a small antigenically related virus, from faecal specimens of several normal dogs and characterized it as 'Minute virus of canine' (MVC) or canine Parvovirus (CPV) type-1. Appel et al. (1978), reported the first epizootic of a new enteric disease of dogs in which, vomiting and diarrhea were the prominent symptoms. Similar syndrome in young puppies caused by myocarditis and congestive heart failure, was simultaneously reported (Hayes et al., 1979). A parvovirus was demonstrated and isolated from these cases and classified as canine parvovirus type 2 (CPV-2). At present, $\mathrm{CPV}-2$ is the most common agent causing clinical disease, throughout the world including India. (Murphy et al., 1999).

Canine parvovirus 2 (CPV2), a non- enveloped icosahedral virus, with an approximate diameter of 20 $\mathrm{nm}$, is the member of genus Parvovirus of the family, Parvoviridae virus is a single-stranded DNA virus, which have 5,200 nucleotides. The virus contain two structural (VP1 and VP2) and two non-structural (NS1 and NS2) proteins. (Notomi et al., 2000).

The CPV replicates in enteritis in dogs of all ages groups and causes myocarditis in young pups. The virus infects rapidly and divide in host cells viz. bone marrow cells, intestinal cells, lymph system cells, and fetal cells. In vitro, MDCK, CFRK (Gupta et al., 2005) and A- 72 (Yilmaz et al., 2005) cells were used, for its isolation and characterization.

CPV withstands in the environment and dog keeping house, and transmitted indirectly or directly in dogs and cats. The major impact of CPV on humans is economical and psychological. Serological survey conducted among kennel and laboratory workers, have failed to find any evidence that CPV is transmissible to human. Hence $\mathrm{CPV}$ is not considered as pathogen with zoonotic potential.

Canine parvovirus (CPV) is responsible for acute gastroenteritis in pups, with a high rate of mortality 
(Carmichael and Binn, 1981). Parvovirus infection in dogs caused by CPV-2, has become an alarming problem in India, causing high morbidity and low mortality. Canine Parvovirus disease was recognized by vomiting and diarrhea in pups with morbidity rate upto $100 \%$ and frequent mortality rate up to 7.5 to 24 percent (Sahu et al., 2007), that may reach upto 69 percent in young pups (Horner, 1983).

There are two canine parvovirus strains viz. CPV2a and CPV2b, which were identified in year 1979 and 1984, respectively (Shackelton et al., 2005). Most of the dogs are infected by above two strains (Martella et al., 2005). Decaro et al., 2006 discovered a third type, CPV2c (a Glu-426 mutant) in Italy, Vietnam, and Spain.

\section{GENOMIC CHARACTERIZATION}

In 1985, the nucleotide sequence of the coat protein gene of canine parvovirus was studied by Rhode (1985). Later, Reed et al., (1988) studied the nucleotide sequence of the entire genome of canine parvovirus and its organization. The CPV genome is of 5323 nucleotide in length, having two major open reading frames (ORF). The ORF in the 3' half of the genome that encodes the non structural proteins NS1 and NS2, while the ORF in 5' half of the genome encodes the structural protein VP1 and VP2. The structural and non structural proteins are initiated from separate promoters. The mRNA of the non structural and structural proteins has co-terminal poly (A), addition sites and spliced to allow alternate templates for protein synthesis.

\section{VP1/VP2 Gene}

Location of VP1 gene, is in 2253 bases whereas, VP2 gene is found 1755 base. The VP2 monomer comprised of an 8 -stranded anti parallel $\beta$-barrel, with large loops inserted between the $\beta$-strands making up most of the exposed surface of the capsid. Surface feature of the capsid included a raised area (spike), surrounding the three-fold axis of symmetry, a depression (dimple) spanning the two-fold axis of symmetry, and a further depression area (canyon) surrounding the five fold axis of symmetry of capsid. Two primary antigenic sites on the three-fold spike of the virus, were defined using monoclonal antibodies (Mab) (Strassheim et al., 1994), although epitopes have also been defined by peptide mapping, in other regions of the capsid (Langeveld et al., 1993). There are three locations on capsid, which can affect canine host range on three fold spikes, which are separated by 25 to 30 Á each other, that is altimetly affects on the flexibility of loops, interactions in virus-receptors or uncoating of capside (Llamas-Saiz et al., 1996).

\section{Hemagglutination Property}

Heamagglutination is an important property of canine parvovirus. CPV bind to pig erythrocytes, rhesus monkey and African green monkey (Gagnon and Povey, 1979). Senda et al., (1986) reported that, observed RBC of horse/ dog/ sheep/mouse etc are agglutinated by CPV. Hemagglutination (HA) property of CPV and FPV were different, due to binding ability to the specific sialic acids. The first difference is that, the FPV isolates haemagglutinate, only in the buffers at pHs below 6.6, while the CPV isolates haemagglutinate at higher pHs up to at least $\mathrm{pH} 7.5$ (Parrish et al., 1998). The HA specificity of the virus, appears to be specific for the sialic acid N-glycolyneuraminic acid, which is present only on feline erythrocytes of the A blood group (about $70 \%$ of almost all the breeds of domestic cat), but now present on the erythrocytes of most breeds of dogs.

\section{HOST RANGE}

These infect warm-blooded animals ranging from domestic fowl to human. These are among the most antigenic 
infectious agents and active infection of animal results in relatively high and persistent antibody levels and long lasting passive immunity in offspring's. Parvo virus responsible for infection is usually sub-clinical, but may affect the fetus, goose parvovirus causes lethal diseases in goslings. Rodent parvoviruses are used as a model in studies of the pathogenesis of certain fetal abnormalities, and are common contaminants of cultured rodents cells and tumors. In humans B19 parvovirus has been incriminated as the cause of a common exanthematous disease, erythema infectious. Parvoviruses have been isolated from chickens, rabbits and an equine fetus, but their role in causing disease in these species has not been established.

\section{SYMPTOMS}

- Depression

- Animal suffering from fever

- Animal may be dehydrated and anorectic

- Severe bloody diarrheas

- Vominting and restlessness

\section{TRANSMISSION}

The virus is transmitted to susceptible host by the faecal-oral route. In recent time it is believed that, one virus does not infect the other species. CPV 2 can undergo mutation to infect the other. FPV is similar to CPV and this similarity is up to 80 per cent or more than that (Ikeda et al., 2000). As compared to dog, this virus (CPV-2) is found more in cats. The virus is not reported in birds and human being, but both act as a carrier, which altimetly infect the dogs and cats (Murphy et al., 1999).

- Mochizuki et al., in 1996, isolate the CPV from faecal sample of cat, manifesting clinical signs of feline panleukopenia and suggested FPLV and CPV, which is transmitted between cats and dogs and also canine disease in other adventitious host.

\section{DIAGNOSIS}

Diagnosis of CPV infection is based on detection of virus by electron microscopy, Serological tests and by molecular techniques. Tentative diagnosis can be made on the basis of the clinical symptoms and history but for confirmatory diagnosis the clinical samples of choice are faeces and pieces of tonsil, spleen and lymph nodes.

The virus in the faeces can be detected by HA test, with pig erythrocytes. (Carmichael et al.,1980; Durigon et al.,1987; Senda et al., 1986) and ELISA test. Isolation of the virus from faeces and other tissues can be made, during the acute stage of the disease. The virus particles in the faces can also be demonstrated under electron microscopy, by negative staining. ELISA test is useful to detect the viral antigen in faeces and clinical samples (Durigon et al.1987; Teramoto et al., 1984).

Isolation of virus is the most sensitive method, for detecting low concentrations of virus in fecal sample. The virus can be isolated in primary canine cells, or in several different canine or feline cell lines like canine A72 cells and crandell 
feline kidney cell line (CRFK). The MDCK canine kidney cell line is reported to be, not susceptible to CPV2 infection.

The virus specific antibodies in serum samples can be detected by HI and ELISA tests. The HI test is reliable, when high antibody titre (1:100) is present. Presence of nonspecific inhibitors of HA test may be present in some sera, which may give false positive reaction and this can be removed by treating the sera with kaolin.

\section{Virus Isolation}

The isolation and identification of virus has been a consistent and most appropriate method. The CPV was successfully isolated and identified, using cell cultures and cell lines such as in MDCK and CFRK (Gupta et al., 2005) and A- 72 (Yilmaz et al., 2005) cells were used for its isolation and characterization. CPV infect not only the canine cell line, but also infect the feline cell line whereas, FPV only infect the feline cells.

\section{Electron Microscopy}

Negative stain electron microscopy has been used to detect CPV particles (Hamilton et al., 1995). Cho et al., (2004), found electron microscopy to be 90 percent sensitive and 40 percent specific in detecting CPV in faecal samples. Although EM is highly specific and sensitive, it often is too time consuming and expensive for routine use in a clinical setting Cho et al., (2006).

\section{Serological Tests}

The simplest and reliable procedure for laboratory diagnosis of canine parvovirus infection, is the detection of $\mathrm{CPV}$ antigen in faecal extracts by heamagglutination test using pig or rhesus monkey red blood cells at $\mathrm{pH} 6.5$ and at $4^{0} \mathrm{C}$ temperature (Kumar et al., 2003). The specificity this hemagglutination is determined by titrating the fecal specimen in parallel in the response of normal and immune dog serum. Fecal sample from dogs with acute enteritis may contain up to 20,000 hemagglutinating units of virus, equivalent to about $10^{9}$ virions, per gram (Murphy et al., 1999).

Kumar et al., (2003) studied the haemagglutinating activity of canine parvovirus to standardize the haemagglutination (HA) test for the diagnosis of canine parvovirus (CPV) infection in dogs using erythrocytes of different species. The HA titre of $<1: 8$ was considered negative. The authors suggest that the HA test can be used easily and successfully for the detection of parvovirus in faecal samples of dogs excreting the virus.

Timbol et al., in 1983 made the diagnosis of canine parvovirus enteritis by the combined use of hemagglutination and hemagglutination inhibition tests on fecal specimens of suspected cases of canine parvovirus enteritis.

Other serological tests used include ELISA (Phukan et al., 2005), Dot Immunobinding (DIA) (Sanousi, 1990), Counter current immunoelectrophoresis (CIE) (Joshi et al., 2000), Immune Electron Microscopy (IEM) (Mochizuki et al., 1984), Agar gel immunodiffusion test (AGID) (Gunaseelan et al., 1993), Fluorescent Antibody Technique (FAT) (joshi $e t$ al., 1996), Single Radial Haemolysis test (SRHT) (Fastier, 1981), Latex agglutination test (Subhashini et al., 1997) and Co agglutination test (Singh, 2002). Singh (2002) has compared HA, AGID, CIE, Single radial immunodiffusion (SRID), DIA, ELISA and Slide Coagglutination tests for detection of CPV antigen in faecal samples and reported that the ELISA was most sensitive while HA and Coagglutination has almost similar sensitivity. The authors advocated coagglutination test to be specific and easy to perform while HA test to be good for screening the field samples but not a confirmatory test. AGID a CIEP tests were found to be specific but less sensitive. 


\section{Molecular Techniques}

A battery of molecular techniques has been in use for detecting CPV in samples. Insitu hybridization (ISH) was standardized by Yoshio et al., (1984) and Cho et al., (2004) for detection of CPV in faecal samples. Cho et al., (2004) while comparing ISH with PCR and EM, found that the PCR has highest sensitivity, whereas ISH and PCR both were rapid in virus detection. Cho et al. (2006) used ISH to detect CPV in Paraffin embedded tissue samples. Meerarani et al., (1998), used Slot Blot Hybridization using non radioactive probes and found it sensitive and specific. The method was reported to be more sensitive than HA.

Polymerase chain reaction has acquired wide acceptance for laboratory diagnosis of virus infections because of its sensitivity and specificity (Gupta et al., 2006). The method is more useful since an appriciable quantity of virus is shed in faecal samples. Silverstein et al., (2003) recommended that, the PCR can be used later in the disease, when potentially fewer viruses are being shed in the feces that may not be detectable by EIA. Shunck et al. (1995) developed a simple touchdown PCR, for CPV and FPV detection.

Loop Mediated Isothermal amplification technique was standardized by Cho et al., 2006, for detecting the CPV DNA in faecal samples. The LAMP technique offers several advantages over PCR analysis, for the detection of CPV-DNA such as, the assay requires only 2 hours to complete and is a sensitive method that can amplify a few copies of DNA to about 109 molecules, in 1 hour under isothermal conditions. When used to detect CPV DNA in a control sample, the LAMP technique had 100-fold higher analytical sensitivity than PCR analysis $\left(10^{-1} \mathrm{TCID}_{50} / \mathrm{ml}\right.$ versus $\left.10 \mathrm{TCID}_{50} / \mathrm{ml}\right)$.

\section{PREVENTION AND DECONTAMINATION}

A puppy that recovers from CPV2 is immune to re-infection, for at least 20 months. There are good co-relations between serum antibody titre, determined by HI or virus neutralization test and the resistance to infection. Attenuated live vaccines are available, which may be given at 6.9 and 12 week age and revaccination carried out annually. However many puppies continue to break with the disease, between their first and second or second and third immunization, or even after the entire vaccine series is complete. Primary cause of failure, of most CPV 2 vaccine is, interfering level of maternally derived antibody (MDA). The presence of MDA, the ability of a vaccine to elicit a serological response has been found to be related to antigenic mass in the dose of the vaccine. Experimental vaccine containing optimum level of CPV-2b induced seroconversion rate of 95 per cent in puppies, with serum neutralization titre of 1: 128. (Information Sheet Canine Parvovirus, 2008-2009).

$\mathrm{CPV}$ infection is quite common and the disease is usually controlled, using a live or inactivated vaccine, although maternally derived antibodies may inhibit the replication of live attenuated vaccines in puppies having temporary immunity. Commonly, CPV causes disease in unvaccinated 1-6 month-old pups (Elia et al., 2005). Twelve month old age dogs are not susceptible to CPV infection, because of pre-vaccination or by the infections with a field virus strain (Truyen 2006). Untreated cases of CPV2 will have a mortality approaching $91 \%$. With aggressive therapy, survival rates may approach 80-95\% (Prittie et al., 2004).

\section{TREATMENT}

There is no specific treatment against this viral infection. Antibiotics like tetracycline; chloramphenicol may be administered for 5-10 days. Attempt should be made to prevent secondary bacterial invasions. 
Symptomatic treatment should be done to control diarrhoea. Preparation containing kanamycine sulphate, pectin; bismuth sub carbonate and activated attpulgite may be tried.

Dehydration should be controlled with ringer lactate or dextrose, with sodium chloride $(\mathrm{NaCl})$. In severe blood looses, plasma volume expander may be used.

Canine parvovirus strain (CORNELL 780916) modified by passages on cell culture is commonly used as a vaccine against the disease. The vaccine is given by $\mathrm{I} / \mathrm{M}$ or $\mathrm{S} / \mathrm{C}$ route followed by second injection after $12^{\text {th }}$ weeks (Macintire et al., 2004).

\section{CONCLUSIONS}

Canine parovirus is largely prevailing in dog and it appears to be a predominant cause of gastroenteritis in dogs. This canine parvovirus also affects the wild range of wild animals. A clinical sign of parvoviral disease was seen in captive and free ranging coyotes. The CPV2 was also circulates among domestic as well as canids. Vaccinated pups are usually protected from this disease and from infection. Sometimes vaccination against canine parvovirus does not provide foolproof coverage against the disease and infection in pet dogs, one reason of failure of vaccination may be the mismatching of the vaccine strain and outbreak strains of CPV. This difference may be due to the mutation in virus and new alleles that changes the strain and properties of the virus. So, properly vaccinate the animal along with adopting serosurveillance programme to totally control the disease in dog and cat population.

\section{REFERENCES}

1. "Information Sheet Canine Parvovirus". Davis, U. C., http://www.sheltermedicine.com/portal/is_parvovirus_canine.shtml\#spread. Retrieved on 2008-08-29.

2. Appel, M.J.G., Cooper, B.J., Greisen, H. and Carmichael, L.E. (1978). Status report: Canine viral enteritis. J. Am. Vet. Med. Assoc. 173:1516-1518.

3. Binn, L. N., Lazar, E. C., Eddy, G. A. and Kajima, M. (1970). Recovery and characterization of a minute virus of canines. Infect. Immunol. 1: 503-508.

4. Burtonboy, G., Coignoul, F., Delferriere, N. and Pastoret, P. P. (1979). Canine haemorrhagic enteritis: Detection of viral particles by electron microscopy. Arch. Virol. 61:1-11.

5. Carmichael L.E., Binn L.N. (1981). New enteric virus in the dog. Adv. Vet. Sci. Comp. Med. 25: 1-27.

6. Carmichael, L. M., Joubert, J. C. and Pollock, R. V. (1980). Hemagglutination by canine parvovirus: serologic studies and diagnostic applications. American J. Vet. Res. 40: 784-791.

7. Cho, H. S. Kang, J. I. and Park, N.Y. (2006). J. Vet. Diag. Invest., 18: 81-84.

8. Cho, H.S., Song, J.E., Park, Y.S. and Park, N.Y. (2004). Diagnosis of the canine parvovirus in faecal samples by in situ hybridization. International Vet. J. 81: 855-859.

9. Decaro, N., Martella, V., Desario, C., Bellacicco, A., Camero, M., Manna, L., d'Aloja, D., Buonavoglia, C. (2006). "First detection of canine parvovirus type $2 c$ in pups with haemorrhagic enteritis in Spain". J. Vet. Med. B Infect. Dis. Vet. Public Health 53 (10): 468-72.

10. Durigon, E.L., Angelo, M.J.O., Jerez, J.A., Tanaka, H. and Hagiwara, M.K. (1987). Comparação entre as reações de hemaglutinação (HA), isolamento do vírus em culturas celulares (CC), imunoeletrosmoforese (IEOF) e imunomicroscopia 
eletrônica (IME), para o diagnóstico etiológico da parvovirose canina. Revista de Microbiologia, 18:.205-210.

11. Elia, G., Cavalli, A., Cirone, F., Lorusso, E., Camero, M., Buonavoglia, D. and Tempesta, M. (2005). Antibody levels and protection to canine parvovirus type 2. J. Vet. Med. B Infect. Dis. Vet. Public Health. 52: 320-322.

12. Fastier, L. B. (1981). A single radial haemolysis test for measuring canine parvovirus antibody. Vet. Rec. 299-301.

13. Gagnon, A. N. and Povey, R. C. (1979). A possible parvovirus associated with an epidemic gastroenteritis of dogs in Canada. Vet. Rec. 104: 263-264.

14. Gunaseelan, L., Ramkrishna, J., Ganesan, P. I. and Manicham, R. (1993). Rapid assay for canine parvovirus by agar gel immunodiffusion test. Indian J. Ani.Sci. 22: 108-110.

15. Gupta, P.K, Rai, A., Rai, N., Raut, A.A., and Chauhan, S. (2005). Cloning of canine parvovirus VP2 gene and its use as DNA vaccine in dogs. Cur. Sci. 88(5): 778-782.

16. Gupta, P.K., Raut, A.A., Dimri, U. and Rai, A. (2006). Rapid PCR-based method for detection of canine parvovirus in dog faeces. Indian J.Virol. 17(2): 78-81.

17. Hamilton, R. C., Drain, D. P. and Smith, H.V. (1995). Vet. Microbiol. 46:307.

18. Hayes, M.A., Russell, R.G. and Babiuk, L.A. (1979). Sudden death in young dogs with myocarditis caused by parvovirus. J. Am. Vet. Med. Asso. 174: 1197-1203.

19. Horner, G. W. (1983). Canine parvovirus in New Zealand: epidemiological features and diagnostic methods. New-Zealand Vet. J. 31(9): 164-166.

20. Ikeda, Y., Mochizuki, M., Naito, R., Nakamura, K., Miyazawa, T., Mikami, T. and Takahashi, E. (2000). "Predominance of canine parvovirus $(C P V)$ in unvaccinated cat populations and emergence of new antigenic types of CPVs in cats." Virol. 278 (1): 13-19.

21. Joshi, D.V. (1996). Clinico- pathological studies on parvovirus infection in dogs. Thesis, Ph.D. G.B. Pant University of Agri. And Tech., Pantnagar.

22. Joshi, D.V., Singh, S. P., Rao, V. D. P. and Patel, B. J. (2000) Diagnosis of canine parvovirus infection by counter immunoelectrophoresis. Indian Vet. J. 77(10): 899-900.

23. Kumar, P., Garg, S. K., Bandyopadhyay, S. K., Singh R., Shrivastava, S. (2003). Haemagglutinating activity of canine parvovirus. Indian J. Ani. Sci. 73(2): 123-125.

24. Langeveld, J. P., Casal, J. I., Vela, C., Dalsgaard, K., Smale, S. H., Puijk, W. C. and Meloen, R. H. (1993). B- cell epitope of canine parvovirus: distribution on the primary structure and exposure on the virus surface. J. Virol. 67: 765-772.

25. Llamas- Saiz, A.L., Agbandje-McKenna, M., Parker, J.S.L., Wahid, A.T.M., Parrish, C.R. and Rossamann, M.G. (1996). Structural analysis of a mutation in canine parvovirus, which controls antigenicity and host range. Virol. 225: 65-71.

26. Macintire and Douglass, K. (2004). "Management of Severe Parvoviral Enteritis". Proceedings of the Western Veterinary Conference. Retrieved on 2007-06-26

27. Martella, V., Cavalli, A., Decaro, N., Elia, G., Desario, C., Campolo, M., Bozzo, G., Tarsitano, E. and Buonavoglia, C. (2005). "Immunogenicity of an intranasally administered modified live canine parvovirus type $2 b$ vaccine in pups with maternally derived antibodies". Clin. Diagn. Lab. Immunol. 12 (10): 1243-5.

28. Meerarani, S., Ramadass, P., Sophy, A. J. R. and Nachimuthu, K. (1998). Slot blot hybridization for diagnosis of canine 
parvovirus infection. Indian J. Virol. 14(1): 43-45.

29. Mochizuki, M., Hida, S., Hsuan, S.W. and Sato, H. (1984). Fecal examinations for diagnosis of canine parvovirus infection. Japanese J. of Vet. Sci. 587-92.

30. Mochizuki, M., Horiuchi, M., Hiragi, H., San-Gabriel, M. C., Yasuda, N. and Uno, T. (1996). Isolation of canine parvovirus from a cat manifesting clinical signs of feline panleukopenia. J. Clin. Microbiol. 34(9): 2101-2105.

31. Mochizuki, M., San Gabriel, M.C., Nakatani, H. and Yoshida, M. (1993). Comparison of polymerase chain reaction with virus isolation and haemagglutination assays for the detection of canine parvoviruses in faecal specimens. Res. Vet. Sci. 55: 60-63.

32. Murphy, F.A., Gibbs, E.P.J., Holzmek, M.K. and Studdert, M.J. (1999). Vet. Virol. 3rd Ed. Academic Press.

33. Notomi, T., Okayama, H. and Masubuchi, H. (2000). Loop-mediated isothermal amplification of DNA. Nucleic Acids Res. 28: e63.

34. Oh, J., Ha, G., Cho, Y., Kim, M., An, D., Hwang, K., Lim, Y., Park, B., Kang, B. and Song, D. (2006). "One-step immunochromatography assay kit for detecting antibodies to canine parvovirus". Clin. Vaccine Immunol. 13 (4): $520-524$.

35. Parrish, C. R., Aquadro, C. and Carmichael, L. E. (1998). Canine host range and specific epitope map along with variant sequences in the capsid protein gene of canine Parvovirus and related feline, mink and raccoon parvovirus. Virol. 166: 293307.

36. Phukan, A., Sarma, D. K., Devajani, D. and Boro, P. (2005). Standardization of ELISA for detection of canine parvovirus infection. Indian Vet. J. 82(4): 355-356.

37. Prittie and Jennifer (2004). "Canine Parvoviral Enteritis: A Review of Diagnosis, Management, and Prevention". J. Vet. Emerg. Crit. Care. 14 (3): 167-176.

38. Reed, A.P., Jones, E.V. and Miller, T.J., (1988). Nucleotide sequence and genome organization of canine parvovirus. J. Virol. 62: $266-276$.

39. Rhode, S. L. (1985). Nucleotide sequence of the coat protein gene of canine parvovirus. J. Virol. 54: 630-633.

40. Saho, N., Parida, G. S. and Sardar, K. K. (2007). Clinical sign-based prognosis of canine parvovirus infection. Indian Vet. J. 84(6): 637-638.

41. Sanousi, A. (1990). Dot based enzyme immunoassay for detection of canine parvovirus antigens in faecal samples of living dogs and organs of dead and stillbirth puppies. Vet. Med. J. 38: 63-76.

42. Senda, M., Hirayama, N., Yamamoto, H. and Kurata, K. (1986). An improved hemagglutination test for study of canine parvovirus. Vet. Microbiol. 12: 1-6.

43. Shackelton, L.A., Parrish, C.R., Truyen, U. and Holmes, E.C. (2005). "High rate of viral evolution associated with the emergence of carnivore parvovirus". Proc. Natl. Acad. Sci. USA 102 (2): 379-384.

44. Shunck, B., Kraft, W. and Truyen, U. (1995). A simple touch-down polymerase chain reaction for the detection of canine parvovirus and feline panleukopenia virus in feces. J. Virol. Methods 55: 427-433.

45. Silverstein, Deborah, C. (2003), "Intensive Care Treatment of Severe Parvovirus Enteritis", International Veterinary Emergency and Critical Care Symposium 2003.

46. Singh, S. P. (2002). Immuno Diagnostic tests for Parvovirus Infection in dog. Intas Polyvet. 3:247.

47. Strassheim, L.S., Gruenberg, A., Veijalainen, P., Sgro, J.Y. and Parrish, C.R. (1994). Two dominant neutralizing antigenic 
determinants of canine parvovirus are found on the three spike of the virus capsid. Virol. 198: 175-184.

48. Subhashini, C.R., Meerarani, S., Ramdass, P. and Nachimuthu, K. (1997). Polymerase Chain Reaction and Latex Agglutination test for detection of Canine Parvovirus Infection. Indian J. Virol. 13:65-68.

49. Timbol, C.R., Seranilla, L.B. and Bain, C.B. (1983).Diagnosis of canine parvovirus enteritis. Philippine J. Vet. Med. 22(1): 6774.

50. Truyen, U. (2006). "Evolution of canine parvovirus - a need for new vaccines?" Vet. Microbiol. 117 (1): 9-13.

51. Yilmaz, Z. (2005) Distribution of Antigen Types of Canine Parvovirus Type 2 in Dogs with Hemorrhagic Enteritis in Turkey. Turkey J. Vet. Anim. Sci. 29: 1073-1076.

52. Yoshio, A.T., Michael, M.M. and Jonathan, C., (1984), Comparison of enzyme-linked immunosorbant assay, DNA hybridization, hemagglutination, and electron microscopy for detection of canine parvovirus infections. J. Clin. Microbiol. 20:373-378. 
